\title{
Governance Structure of Strategic Alliances - Evidences From the South Moravian Region
}

\section{Estélyiová Kristína}

\begin{abstract}
The objective of the paper is to explore the governance structure of strategic alliances created by small and medium enterprises in the South Moravian Region. It deeper examines contractual alliances between strategic partners with focus on the contract and also deals with the protection of intellectual property rights in the investigated firms. To gain data for investigation, both primary and secondary research have been applied. Within the former the main data collection methods were the questionnaire survey and semi-structured personal interviews. The overall goal of the paper is to enhance the knowledge about the creation and functioning of strategic alliances in the Czech Republic.

This paper is organized in the following way: first of all, the notion of strategic alliance is introduced. Next, the main forms of governance structure are presented in more details. This is followed by the objective and the methods of research. The results present the main findings of the research and discuss them in broader context. The conclusions recall the main findings and reveal the space for further investigation.
\end{abstract}

Key words: strategic alliance, governance structure, equity alliance, non-equity alliance, joint venture, minority alliance, contractual alliance, intellectual property rights, SMEs

\section{INTRODUCTION}

Firms have increasingly seen strategic alliances as attractive forms of cooperation through which they can grow and expand (Gulati \& Singh, 1998). While there are plenty of studies dealing with strategic alliances, they may differ in definition of alliance. Commonly, alliance is any cooperative agreement voluntary initiated between firms that can involve "exchange, sharing or co-development, and it can include contributions by partners of capital, technology, or firm-specific assets" (Gulati \& Singh, 1998, p. 781). Haas (1997) furthermore emphasises the pool of risk between partners and the integration of functions in order to reach the joint goals. Buzády and Tari (2005) note that cooperation in an alliance is principally long-term, lasting obviously more than one year.

In order to remain competitive, firms must react to the signals from their environment continuously. To do so, a flexible access to several tangible and intangible resources is needed, which is often difficult, especially in case of small and medium enterprises (SMEs). Ring and Van de Ven (1992, p. 483) notify that alliances represent an efficient way to keep pace, especially in case firms are seeking "unique and pioneering resources".

Thanks to globalization the creation of inter-organization connections is growing in intensity. Vodáček and Vodáčková (2002) emphasise that recent strategic alliances create complex networks consisting of bilateral connections. They involve not only firms, their customers, 
suppliers, investors and other stakeholders, but also organizations, as research centres and universities. These complex networks have undoubtedly great importance, but in order to gain more specific results, the attention in the research described in this paper is focused only on inter-firm alliances.

Previous researches has also pointed out that along with the growing number of alliances there is an increase in diversity. According to Gulati and Singh (1998) one of the determinants are the formal structures used to organize the cooperation. This topic has been a subject of numerous researches (Das \& Teng, 1996; Casciaro, 2003; Comino et al., 2007; Kuittinen et al., 2009). Parkhe (1993) sees alliance structure as a critical determinant of alliance performance.

Research in the Czech Republic in the field of strategic alliances lags behind the Western European countries in volume and results. One of the reasons is undoubtedly the lack of interest and activity of the SMEs. According to Zelený (2011) the problem lies in the culture of entrepreneurship and the way entrepreneurs look at cooperation in the Czech Republic. In many cases the effort for self-sufficiency and the protection of know-how are preferred to creation of closer cooperation with the business partner.

The investigation of alliances and other forms of cooperation based on networks is included in the publications of Pitra (2001), Lednický and Vaněk (2004), Skokan (2004), Mikoláš (2005), Nenadál (2006), Vodáček and Vodáčková (2006), Dědina and Odcházel (2007), Blažek et al. (2009) and others. However, the current state of knowledge in the Czech Republic still lacks results from researches focusing on certain aspects of alliance formation, such as the early stages of formation, alliance management practices, alliance performance measurement, dissolution of alliances. Governance structure is also one such area.

\section{ALLIANCE STRUCTURE}

Alliance structure embodies a certain degree of hierarchical elements which can be characterized by the extent of control and coordination (Gulati \& Singh, 1998). Prior research influenced primarily by transaction cost theory have focused in great deal on the appropriation concerns in alliances originating from contracting obstacles and pervasive behavioural uncertainty. The researchers have observed that the greater the appropriation concerns, the more hierarchical the governance structure of the future alliance tend to be enabling hierarchical controls in the form of control by fiat, monitoring and alignment of incentives.

Thanks to the variety of organization structures firms face numerous possibilities in structuring their alliance. In relation with this variety there is an incoherrence among researchers in determination of what alliance is. Some of them (Vodáček \& Vodáčková, 2006) consider alliance in its most narrow sense only cooperation without any share of equity. Others (Buzády \& Tari, 2005), include also cooperation with minority equity share between firms. The widest definition of alliance involves common equity of partners - joint venture (Das \& Teng, 1998; Gulati \& Singh, 1998; Arino, 2003; Child, 2005; Comino et al., 2007). The author of the paper follows the latter way of understanding alliance. 


\subsection{Determinants of alliance structure}

Scholars in previous researches have distinguished and studied several determinants of alliance structure. The most frequent of them are the followings:

- the volume of anticipated coordination costs at the time of alliance formation - the greater the volume of anticipated coordination costs, the more hierarchical the governance structure was (Gulati \& Singh, 1998);

- the complexity of arrangements - they are related with the anticipated coordination costs of cooperation; the higher the complexity the higher the anticipated coordination costs of the alliance (Gulati \& Singh, 1998; Dent, 2003);

- repeated ties between the partners - repeated ties diminish hierarchical controls in alliances (Gulati \& Singh, 1998);

- the existence of prior dealings or a social network between the parties - previous relations between the parties can reduce moral hazard problems and diminish hierarchical controls in alliances (Gulati \& Singh, 1998; Dent, 2003).

Careful investigation of these determinants by the parties should result in a proper alliance governance structure design.

\subsection{Classifying governance structures}

Researchers have distinguished dimensions of hierarchical control in distinct types of alliances, where each of them can be characterized by specific levels and forms of command structure and authority systems, standard operating procedures, incentive systems, dispute resolution procedures, etc. (Gulati \& Singh, 1998).

\section{Non-equity or contractual alliances}

Contractual alliances are similar to arms-length market exchanges in sense of the independency of the parties and their equal basis for business (Gulati and Singh, 1998). Partner firms work together directly from their own organization without equity share or unification under common ownership. Activities are coordinated jointly and the decisions are made by negotiations among the partners. Wang and Nicholas (2007) acknowledge that contractual alliances are characteristic for the openness and flexibility of contracts allowing the negotiation of terms and conditions between the partners continuously. They can be established quickly as a reaction to a concrete need or business opportunity and dissolved after completion the negotiated objective. Moreover, the transaction costs of entering and exiting the contractual alliance are reduced which can be of a special importance for SMEs.

\section{Minority alliances}

According to the degree of hierarchical control, minority alliances represent the middle of the spectrum. Cooperating partners take minority equity position in the other (or others) to establish more precise coordination and control than it is obvious in contractual alliances. However, these efforts are relatively limited as - according to Gulati and Singh (1998, p. 792) - these investments "typically do not have a separate organization and administrative structure". 


\section{Joint ventures}

Gulati and Singh (1998) rank joint ventures to end of the hierarchical spectrum. Firms create a separate entity in which each partner owns a portion of the equity. On the strategic level joint ventures are governed by a board of directors, which is composed of members from all partner firms (Sampson, 2003). Moreover, joint ventures can be characterized by autonomous command structure and authority system as day-to-day operation is overseen by independent managers. This highly hierarchical organization requires clearly defined rules and responsibilities and the establishment of incentive systems and dispute resolution systems (Gulati \& Singh, 1998). The drawback of high level coordination and control are especially the costs of such mechanisms. Therefore Sampson (2003) suggests establishing joint ventures only in case the alliance activities require more substantial coordination and control. Tab. 1 summarizes the main forms of inter-firm cooperation, from ordinary contracts to joint ventures, and represents them in order according to the degree of cooperation and control.

Tab. 1 - The main forms of interfirm cooperation. Source: the author based upon Buzády \& Tari (2005) and Wang \& Nicholas (2007, p. 134)

\begin{tabular}{|c|c|c|}
\hline $\begin{array}{l}\text { Main forms of inter-firm } \\
\text { cooperation }\end{array}$ & Contract attributes & Theoretical nature \\
\hline $\begin{array}{l}\text { Ordinary contracts as buy- } \\
\text { ing and selling contracts, } \\
\text { ordinary subcontract- } \\
\text { ing, framework contracts, } \\
\text { processing and assembling } \\
\text { contracts }\end{array}$ & $\begin{array}{l}\text { Especially short-term con- } \\
\text { tracts lacking any compo- } \\
\text { nent of permanent, strategi- } \\
\text { cally important cooperation }\end{array}$ & arm's length contracts \\
\hline Contractual alliances & $\begin{array}{l}\text { Firms work together on a } \\
\text { range of projects, the activi- } \\
\text { ties are jointly coordinated } \\
\text { and decisions are made by } \\
\text { negotiations. }\end{array}$ & $\begin{array}{l}\text { non-equity alliances, uni- } \\
\text { directional or bidirectional } \\
\text { agreements, high rate of } \\
\text { strategic flexibility }\end{array}$ \\
\hline Minority alliances & $\begin{array}{l}\text { Firms own minority equity } \\
\text { in their partner organiza- } \\
\text { tions obviously without crea- } \\
\text { tion of joint organization } \\
\text { and administrative structure. }\end{array}$ & $\begin{array}{c}\text { equity-based alliances } \\
\text { without unified governance, } \\
\text { medium rate of strategic } \\
\text { flexibility }\end{array}$ \\
\hline Joint ventures & $\begin{array}{l}\text { Firms create a separate } \\
\text { entity in which each partner } \\
\text { owns a portion of equity } \\
\text { characterized by independ- } \\
\text { ent command structure and } \\
\text { authority system. }\end{array}$ & $\begin{array}{l}\text { equity-based alliances with } \\
\text { unified governance, low rate } \\
\text { of strategic flexibility }\end{array}$ \\
\hline
\end{tabular}


From this typology mergers and acquisitions were left out intentionally, as these structures do not allow for the legal and functional independence of all parties.

\subsection{Problems in cooperation coordination}

Despite the potential benefits of cooperation within a strategic alliance, there are substantial barriers to scrutinize. Therefore, allying firms should find the balance in allocating their resources between their own organization and the partner(s) (Haas, 1997).

Sampson (2003) formulates three main problems in the field of cooperation coordination the firms entering strategic alliances face. First of all, there are considerable moral hazard problems since partner's behaviour is often unforeseen. Moreover, equal contribution of partners to the alliance activities is difficult to control and the costs of their opportunism may be high. This can bear particular importance in alliance with uncertain outcomes or where firms undertake complex activities requiring high-end technologies. Second, there is the risk of unintended transfer of the firm's most valuable assets to partners, arising from the imperfect protection of intellectual property rights. These assets are those which can distinguish the firm from its competitors, such as technologies, product specifications, techniques, information about markets and customers, key strategies and business practices or other forms of knowledge. Last, differing managerial methods, strategic interests and expectations of partners can manifold the difficulties of alliance cooperation coordination.

Sampson (2003) notifies that there is a means to deal with cooperation coordination problems - the alliance structure. Formal structure is a means enabling to set out partner rights and obligations, define and follow alliance goals, and provides a framework for decision making and problem solution. The author emphasizes that even if not all embedded in the contract and inner rules is legally enforceable, thorough planning of alliance structure may reduce the occurrence of misunderstandings and activities which are out of line with the alliance goals.

\section{OBJECTIVE AND METHODS}

The objective of the paper is to explore the governance structure of strategic alliances created by SMEs in the South Moravian Region. It deeper examines contractual alliances between strategic partners with focus on the contract. As during cooperation there is a risk of unintended transfer of knowledge and technology between partners (Sampson, 2003) it also deals with the protection of intellectual property rights in the investigated firms. Dent (2003) notes that business organization and contract terms, as well as the allocation of property rights should be a part of any serious examination of alliances. The overall goal of the paper is to enhance the knowledge about the creation and functioning of strategic alliances in the Czech Republic.

In order to explore the characteristic features of strategic alliances in the Czech Republic, both qualitative and quantitative research methods were applied. The basic sample consisted of SMEs from the South Moravian region. The common feature of these firms was that they carry out R\&D in the Czech Republic within their primary or secondary activities "irrespective to number of employees, sector of performance and economic activity" (Czech Statistical Office, 2011, p. 1). The dataset creates a part of the Czech Statistical Office database (2010) and contains 637 firms - SMEs. 
Within the framework of quantitative research a questionnaire survey has been conducted among these firms. The minimum required sample size has been calculated according to Saunders et al. (2007, p. 613-614) and has been estimated to 66 at $95 \%$ confidence level and $5 \%$ margin of error. In order to obtain a representative sample the self-selection sampling technique has been used. From the given dataset 401 firms were contacted by telephone, e-mail or both of them between November 2010 and January 2011. There were three rounds of contacting at all. The active response rate was $33 \%$ (for more details see Tab. 2). The questions in the questionnaire were organized into several blocks according to topic, starting with basic information of firms, followed by characteristics of strategic alliance and governance structure, closing with overall evaluation of cooperation.

Tab. 2 - Response rate. Source: author

\begin{tabular}{|c|c|c|c|}
\hline $\begin{array}{c}\text { Means of data } \\
\text { collection }\end{array}$ & $\begin{array}{c}\text { Number of con- } \\
\text { tacted firms }\end{array}$ & $\begin{array}{c}\text { Number of completed } \\
\text { questionnaries }\end{array}$ & $\begin{array}{c}\text { Response rate } \\
\text { (\%) }\end{array}$ \\
\hline Telephone & 105 & 40 & 38 \\
\hline E-mail & 296 & 92 & 31 \\
\hline Total & 401 & 132 & 33 \\
\hline
\end{tabular}

Within the framework of qualitative research three firms from the sample were deeper questioned about certain features of strategic partnership with an aim to verify the information gained from the questionnaire, to explain some of these information more thoroughly and to expand the overall knowledge about strategic cooperation. The interviews were conducted in March 2011 with the top managers or directors of the firms in a length of about 45 minutes. During these personal meetings semi-structured questionnaire was used in order to ensure the comparability of results. The business names of firms in this article are omitted. According to the firm law of English-speaking countries, two of them are limited firms, and the third one is a joint-stock firm. For more information see Tab. 3. In the paper the outcomes of these interviews has only complementary function, they are presented very briefly giving additional proof to the questionnaire research findings or to comment some of the results.

Tab. 3 - Personal interviews - overview of firms' basic information. Source: author

\begin{tabular}{|c|c|c|c|c|c|c|}
\hline Firm & $\begin{array}{c}\text { Legal } \\
\text { form }\end{array}$ & Size & $\begin{array}{c}\text { Branch of } \\
\text { business }\end{array}$ & $\begin{array}{c}\text { Type of } \\
\text { business }\end{array}$ & $\begin{array}{c}\text { Number of } \\
\text { strategic partners }\end{array}$ & $\begin{array}{c}\text { Cooperation } \\
\text { with } \\
\text { competitors }\end{array}$ \\
\hline Firm A & plc & small & ICT & services & more than 3 & yes \\
\hline Firm B & Ltd. & micro & ICT & services & 2, exceptionally 3 & yes \\
\hline Firm C & Ltd. & small & $\begin{array}{c}\text { machinery } \\
\text { industry }\end{array}$ & services & 2, exceptionally 3 & yes \\
\hline
\end{tabular}

Besides primary research a great emphasise was put also on the secondary research drawing upon research papers from electronic databases, books, annual reports, organizations' webpages and the author's previous research papers. 


\section{RESULTS AND DISCUSSION}

From the selected sample of 132 firms the ones with at least one strategic business relation were filtered out. These firms were further questioned about the details of strategic cooperation with regard also to the governance structure and its details.

\subsection{Governance structure of strategic alliances of investigated firms}

Following the governance structure categorization in chapter 2.2, respondents could mark the most characteristic type(s) of formal organization of their strategic cooperation. They could choose one or more characteristic structure from: contractual alliance, minority alliance and joint venture. The category of contractual alliances has been further divided into two subcategories: oral agreements and written contracts, as both can be used in practise in the Czech Republic (Tab. 4).

Tab. 4 - Governance structure of strategic alliances of investigated SMEs. Source: author

\begin{tabular}{|c|c|}
\hline \multirow{2}{*}{ Governance structure } & Sample \\
\cline { 2 - 2 } & Relative frequency (\%) \\
\hline Contractual alliances - oral agreements & 30,5 \\
\hline Contractual alliances - written contracts & 84,2 \\
\hline Minority alliance & 7,4 \\
\hline Joint venture & 6,3 \\
\hline Total & 128,4 \\
\hline Number of respondents & 95 \\
\hline
\end{tabular}

According to the results, the dominance of contractual relationships is evident. More than 84 $\%$ of firms sign written contract with strategic business partners. Furthermore, nearly a third of respondents cooperate under oral agreement. The two other forms of governance structure - minority alliance and joint venture - are not really widespread. The former is present at 7,4 \% of firms and the latter at 6,3\%. These results are in accordance with Pitra's (2001) observation, that the most obvious form of strategic alliance is contractual relationship.

Taking a closer look on the results, it is found that $16 \%$ of firms do not apply written contracts at all. Further investigation has shown that $88 \%$ of these firms create strategic alliances based only on oral agreements. This finding tells about a very precious and sophisticated level of strategic relationship (Zelený, 2011) being characteristic only for $14 \%$ of responding firms. It is based on a very high level of trust and has very loose structure. The personal interview with firm $\mathrm{C}$ gave further support to this finding.

\subsection{Contractual alliances between investigated firms}

As written contracts dominate in the formal structure of investigated firms, the survey focused on the contractual alliances in more details. Respondents who cooperate under contracts could choose from the most typical contract types applied in cooperation as: partnership agreement, contract for work, agency contract, license agreement or other. In case of different practice firms could add their own answers. 
According to the results $78,8 \%$ of respondents sign partnership agreements. These contracts allow for the creation of either loose formal base or expressed structure of cooperation. The second most preferred type of contracts are contracts for work $-48,8 \%$ of firms declared their application. The proportion of firms which have experience with license agreements and agency agreements is rather low, 16,3\% and $11,3 \%$. For more detailed information see Tab. 5.

Tab. 5 - The most preferred types of written contracts. Source: author

\begin{tabular}{|c|c|}
\hline \multirow{2}{*}{ Types of contracts } & Sample \\
\cline { 2 - 2 } & Relative frequency (\%) \\
\hline Partnership agreement & 78,8 \\
\hline Contract for work & 48,8 \\
\hline License agreement & 16,3 \\
\hline Agency agreement & 11,3 \\
\hline Other & 5,0 \\
\hline Total & 160 \\
\hline Number of respondents & 80 \\
\hline
\end{tabular}

The $5 \%$ of respondents having chosen the "other" category revealed the application of additional contract types, as contract for software development, framework agreement and contract of sale.

These results were difficult to compare with findings of similar researches, as a significant part of these works investigate the relation between costs of cooperation and the governance structure, or analyze the content of contracts in greater details than it was possible within this research. Moreover, contract types and business practices in this field can be also country specific.

\subsection{The degree of control and coordination in investigated firms}

The strength of ties within strategic alliance members is a very important factor. It can reveal additional information about the mutual trust of parties, the position of parties within the alliance, and their practices. Firms had to determine the degree to which written contracts specify the parties' rights and obligations. According to the "strength" of the contracts the following three types were distinguished:

- contracts with free specification of rights and obligations of the parties,

- contracts with express specification of rights and obligations of the parties,

- contracts with express specification of rights and obligations of the parties containing terms of penalty for cases of breaching the contractual obligations.

Respondents could choose more than one characteristic answer. Tab. 6 provides an overview of the results. 
Tab. 6 - Types of contracts according to the degree of specification. Source: author

\begin{tabular}{|c|c|}
\hline \multirow{2}{*}{ Degree of specification } & Sample \\
\cline { 2 - 2 } & Relative frequency (\%) \\
\hline Free specification & 16,3 \\
\hline Express specification & 43,8 \\
\hline Express specification containing terms of penalty & 48,8 \\
\hline Total & 108,8 \\
\hline Number of respondents & 80 \\
\hline
\end{tabular}

Among respondents declaring the use of contracts, as many as 92,6\% apply contracts with express conditions. Moreover, nearly a half of these firms have terms of penalty embedded in the contract. This makes $45 \%$ of the total number of described contract types.

Only $16 \%$ of firms prefer looser contracts creating solely the rough framework of cooperation with the strategic partner. This group of respondents apply only this type of contract. According to the director of firm B, the most important part of such contract is the termination provision.

$43 \%$ of firms use only contracts with embedded terms of penalty. The relatively frequent application of this type of contracts may reflect one or more possible situations: the application of standard practise in the firm, the complexity of the tasks within cooperation and also the lack of trust between business partners.

\subsection{Intellectual property protection in the investigated firms}

When analyzing strategic cooperation from legal point of view, there is one important and complex area which should not be forgotten - the intellectual property rights. While cooperation with the partner or partners gets stronger and deeper, the firms' core competencies, strategic plans, methods and processes, information databases etc. can be partly exposed, which means a potential risk of abuse. This risk is especially evident in cases, when firms have only a relatively short cooperation history prior to the strategic alliance (Gulati \& Singh, 1998).

In some cases the protection of intellectual property rights is a prerequisite of building deeper inter-firm relationships. Unfortunately, the framework of this research did not allow to make deeper investigations in this field. Its goal was only to find out whether firms engaged in strategic cooperation protect their IPL in form of patents, utility models, industrial designs and trademarks.

In their answers nearly two-thirds of respondents confirmed the protection of intellectual property at least with one of the most frequent means of protection (see Fig. 1). This relatively high proportion could result from the research and development profile of these firms.

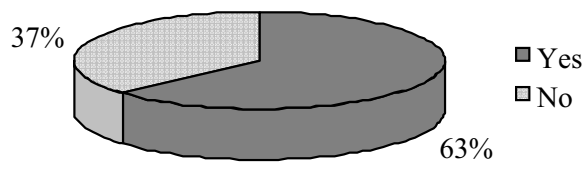

Fig. 1 - Existence of intellectual property protection in investigated firms. Source: author 
According to the statistical information published by the Czech Industrial Property Office (2011), the proportions can be only presumed. On country level trademarks make $54 \%$, patents $31 \%$, utility models $10 \%$ and industrial design $5 \%$ from the main means of protection.

\section{CONCLUSIONS}

Governance structure of strategic alliances can be an important factor determining the success of cooperation. Even though there is a heterogeneity in previous researches about which factors affect the choice of a certain formal structure the most, one point is clear: careful planning is inevitable (Reuer et al., 2006). The strategic importance of cooperation, the complexity and resource intensity of tasks, the existence of previous contact between partners, or the costs of finding the suitable alliance partner may influence the design of the governance structure of future cooperation. In spite this topic is widely discussed in the papers of foreign researchers, there is a lack of information from the Czech Republic. Therefore this paper aimed to explore the strategic alliances of SMEs located in the South Moravian Region. The common feature of these firms was the carry-out of research and development as primary or secondary activity. The research focused on the preferred governance structure, the types of and rigidity of applied contracts and the protection of intellectual property.

The results have proved the dominance of contractual alliances in case of $97,9 \%$ of firms. The set-up of equity alliances - minority alliances and joint ventures - has been found only in case of 7,4 \% respectively $6,3 \%$ of SMEs. Within contractual alliances based on written contracts the application of partnership agreements and contracts for work were the most preferred ways of cooperation formalization (used by $78,8 \%$, respectively $48,8 \%$ of firms). License agreements were declared only in 16,3\% of firms. The interview with firm A revealed that license agreements are often used as supplementary contract to contracts for work.

Investigating the details of applied contracts in alliances, the dominance of express contracts has been revealed (in case of $84 \%$ of respondents). Moreover, $48,8 \%$ of the firms embed penalty provisions into contracts. On contrary $16 \%$ of firms cooperate solely under loose contracts lacking express specification of rights and obligations of partners. As several researchers have stressed, firms should devote a great attention to setting the rules of cooperation and to the contract design (Dent, 2003; Sampson, 2003).

Another important aspect of strategic cooperation is the relative risk of unwanted reveal of core competencies, information and technologies. Therefore, the protection of intellectual property should be carefully considered in the course of alliance formation. Within the investigated sample of firms $63 \%$ of them have declared the ownership of patents, utility models, industrial designs or trademarks as means of protection. Considering the focus of these firms on research and development, this protection can bear high importance.

In this place it is important to note that the presented research has several limitations. First of all, instead of covering the whole country, only the South Moravian Region has been investigated. In spite of this the author of the paper believes, this way has enabled to collect more complex data from one location enabling the gain of more coherent knowledge about these cooperative relationships. Second, there was an attempt to analyze the applied contracts in more details. Unfortunately, the scope of this research did not allow deeper investigation of the 
contract details as terms of cooperation, coordination and control mechanisms, termination and confidentiality provisions, restrictions on proprietary information, the value of penalty and other features. The results have proved the dominance of specified contracts between firms, therefore there is a large space for further research in this area. Last, although the protection of intellectual property is highly important in case of strategic cooperation, the scope of research allowed only for gaining information about the existence of protection. It lacks the analyze of concrete means of protection and their embeddedness in strategic business relations giving space also for future research.

In spite of the limitations the research described in this paper has revealed specific information about governance structure of strategic alliances in the Czech Republic. The author has contributed to the creation of a more concrete picture and emphasizes the importance of structure creation. Moreover, the findings can provide SMEs with information about current business practices and encourage the ones who do business "alone" to consider the opportunity of closer cooperation with a business partner. This is one of the ways of increasing firms' competitiveness in the domestic and foreign markets and the overall competitiveness of the Czech Republic. Bat'a (1936, p. 131) states, “...cooperation is a noble competition heading to only goal: the improvement of human, the improvement of society, the improvement of firms and the avoidance of losses by integration and harmonization of individual potentials."

Development in the field of inter-firm cooperation toward more valuable and intensive relations brings higher quality and different dimension into the recent business relations. Pitra (2001) notifies that while traditional organization structure is suitable for following clearly set strategic goals in a relatively stable environment, it is inefficient in changing conditions. The author further points out that firms which are able to abandon the classical model of management hierarchy and choose looser organization structure, are also able to react more efficiently to the turbulences in their environment. But as Reuer et al. (2006) emphasise, in order to achieve these benefits entrepreneurs have to pay attention to the initial conditions of alliance formation and to the processes within alliance-management. Therefore the design of governance structure is one of the most important tasks of alliance members.

\section{Acknowledgement}

This paper was supported by grant FP-S-11-1 "Rozvoj poznatků ke zdokonalování informační podpory ekonomického rrízení podniku" from the Internal Grant Agency at Brno University of Technology.

\section{References}

1. Ariño, A. (2003). Measures of strategic alliance performance: An analysis of construct validity. Journal of International Business Studies, 34 (1), 66-79. doi:10.1057/palgrave.jibs.8400005

2. Bat’a, J. A. (1936). Spolupráce: Výbor z článkiu a projevũ v letech 1920-1936. Zlín: Tisk.

3. Blažek, L. et al. (2009). Konkurenčni schopnost podnikũ (analýza faktorü hospodáršké úspěšnosti - drubá etapa. Brno: Masarykova univerzita.

4. Buzády, Z., \& Tari, E. (2005). Stratégiai szövetségek a hazai tulajdonú középvállalatok körében [Research Paper, nr. 6]. Budapest: Corvinus Egyetem. Retrieved November 15, 2010, from http:// edok.lib.uni-corvinus.hu/143/1/6_mht_strat\%C3\%A9giai_sz\%C3\%B6vets\%C3\%A9gek. pdf 
5. Casciaro, T. (2003). Determinants of governance structure in alliances: The role of strategic, task and partner uncertainties. Industrial And Corporate Change, 12 (6), 1223-1251. doi:10.1093/ $\mathrm{icc} / 12.6 .1223$

6. Comino, S., Mariel, P., \& Sandonis, J. (2007). Joint ventures versus contractual agreements: An empirical investigation. Spanish Economic Review, 9 (3), 159-175. doi:10.1007/s10108-0069010-2

7. Czech Industrial Property Office. (2011). Annual report 2011 [annual report]. Retrieved March 23, 2012, from http://www.upv.cz/cs/publikace/rocenka/rocenka.html

8. Czech Statistical Office. (2010). Business Register. Retrieved October 31, 2010, from the Czech Statistical Office database.

9. Czech Statistical Office. (2011). Research and development indicators 2010: Methodology [annual report]. Retrieved November 10, 2011, from http://www.czso.cz/csu/2011edicniplan.nsf/ engpubl/9601-11-eng_r_2011

10. Das, T. K., \& Bing-Sheng, T. (1998). Between trust and control: Developing confidence in partner cooperation in alliances. Academy Of Management Review, 23 (3), 491-512. doi:10.5465/ AMR.1998.926623

11. Das, T. K., \& Teng, B. (1996). Risk types and interfirm alliance structures. Academy Of Management Best Papers Proceedings, 11-15. doi:10.5465/AMBPP.1996.4978070

12. Dědina, J., \& Odcházel, J. (2007). Management a moderní organižováni firmy. Praha: Grada Publishing.

13. Dent Jr., G. W. (2003). The role of lawyers in strategic alliances. Case Western Reserve Law Review, 53 (4), 953-963. Retrieved from http://web.ebscohost.com

14. Gulati, R., \& Singh, H. (1998). The architecture of cooperation: Managing coordination costs and appropriation concerns in strategic alliances. Administrative Science Quarterly, 43 (4), 781-814. doi:10.2307/2393616

15. Haas, M. R. (1997). Strategic alliances: Getting it right. Natural Gas (Wiley), 14 (1), 23-27. doi:10.1002/gas.3410140106

16. Child, J. (2005). Organization: contemporary principles and practice. Malden: Blackwell Publishing.

17. Kuittinen, H., Kylaheiko, K., Sandstrom, J., \& Jantunen, A. (2009). Cooperation governance mode: An extended transaction cost approach. Journal Of Management And Governance, 13 (4), 303-323. doi:10.1007/s10997-008-9074-5

18. Lednický, V., \& Vaněk, J. (2004). Kooperačni struktury malých a střednich podnikư. Opava: Slezská univerzita v Opavě.

19. Mikoláš, Z. (2005). Jak zvýsit konkurenceschopnost podniku: konkurenční potenciál a dynamika podnikéní. Praha: Grada.

20. Nenadál, J. (2006). Management partnerství s dodavateli. Praha: Management Press.

21. Parkhe, A. (1993). Strategic alliance structuring: A game theoretic and transaction cost examination of interfirm cooperation. Academy Of Management Journal, 36 (4), 794-829. doi:10.2307/256759

22. Pitra, Z. (2001). Zvyšováni podnikatelské výkonnosti firmy: strategický obrat v podnikatelském chování. Praha: Ekopress. 
23. Reuer, J. J., Ariño, A., \& Mellewigt, T. (2006). Entrepreneurial alliances as contractual forms. Journal of Business Venturing, 21 (3), 306-325. doi: 10.1016/j.jbusvent.2004.09.003

24. Ring, P., \& van de Ven, A. H. (1992). Structuring cooperative relationships between organizations. Strategic Management Journal, 13 (7), 483-498. doi:10.1002/smj.4250130702

25. Sampson, R. C. (2003). The role of lawyers in strategic alliances. Case Western Reserve Law Review, 53(4), 909-927. Retrieved from http://web.ebscohost.com

26. Saunders, M., Lewis P., \& Thornhill, A. (2003). Research methods for business students. Pearson Education Limited.

27. Skokan, K. (2004). Konkurenceschopnost, inovace a klastry v regionálním rozvoji. Ostrava: Repronis.

28. Vodáček, L., \& Vodáčková, O. (2006). Moderní management v teorii a praxi. Praha: Management Press.

29. Wang, Y., \& Nicholas, S. (2007). The formation and evolution of non-equity strategic alliances in China. Asia Pacific Journal Of Management, 24 (2), 131-150. doi:10.1007/s10490-0069034-z

30. Zelený, M. (2011). Krize nebo transformace? Globalizace nebo relokalizace? Unpublished raw data.

\section{Contact information}

Ing. Kristína Estélyiová, Ph.D.

Brno University of Technology, Faculty of Business and Management

Kolejni 2906/4, 61200 Brno

Tel: +420 541143707

E-mail:estelyiova@fbm.vutbr.cz. 